\title{
The Influence of the Andean Intellectual Property Regime on Access to Medicines in Latin America
}

to appear in BALANCing WeAlth AND HEAlth: GLOBAL AdMINISTRATIVE LAW AND the BATTLE OVER INTELLECTUAL PROPERTY AND ACCESS TO MEDICINES IN LATIN AMERICA

(Rochelle Dreyfuss \& César Rodríguez-Garavito, eds. 2013)

\section{Laurence R. Helfer ${ }^{*} \&$ Karen J. Alter ${ }^{* *}$}

The Andean Community, a regional integration pact among a small group of developing countries on the mountainous western edge of South America, entered its fifth decade riven by political and economic schisms. Divisions among the member states have waxed and waned over the years, but in general they have prevented the Community from living up to its potential as the continent's second largest trading bloc. In addition, the Andean Community's supranational institutions - which include a Commission of national executives, a General Secretariat of regional administrators, and a Tribunal of Justice (the ATJ or the Andean Tribunal) ${ }^{1}$ - have had only mixed results in promoting robust economic or political integration. Not surprisingly, many judges, lawyers, civil society groups, and commentators have either ignored the Andean Community or dismissed it as a failure.

Yet the Andean integration project has had remarkable success within one area of its legal system - the rules governing the protection of intellectual property (IP). Those rules are found in extensive and detailed supranational laws - officially known as "Decisions" - that regulate patents, trademarks, copyrights, and other IP subjects. Andean IP Decisions have direct effect and serve as the national IP legislation in each of the member states, occasionally supplemented by domestic IP decrees promulgated by national executives. Once adopted, Andean IP Decisions and domestic IP decrees are interpreted and applied by the ATJ, by national courts, and by IP administrative agencies in each of the member states. The result, as we have explained elsewhere, is an effective rule of law island for IP, an island in which Andean legal rules - rather than power, political influence, or bribery - regulate the behavior and decision making of government officials and private firms (Helfer, Alter and Guerzovich, 2009). ${ }^{2}$

Two aspects of this rule of law island are especially noteworthy. The first is the overwhelming dominance of IP cases on the docket of the Andean Tribunal. Of the 1338 preliminary references that national judges sent to the ATJ through the end of 2007, 1303

\footnotetext{
* Harry R. Chadwick, Sr. Professor of Law, Duke University.

** Professor of Political Science and Law, Northwestern University.

${ }^{1}$ These supranational institutions were modeled on those of the highly successful European Community (Alter, Helfer and Saldías, 2012).

${ }^{2}$ Our published studies of the Andean legal system, summarized in part in this chapter, are based on a systematic coding and in-depth analysis of the decisions of the Andean Tribunal of Justice (ATJ) and interviews with more than forty with judges, government officials, attorneys, and interest groups in Colombia, Ecuador, and Peru.
} 
concern IP. ${ }^{3}$ The domestic origin of these rulings is also remarkably uniform: 1285 cases began as challenges to an administrative agency's decision to grant or deny an application to register a trademark, patent, or other IP right. This striking statistic reveals that IP agency registration decisions are responsible for nearly $96 \%$ of all ATJ preliminary rulings (Helfer and Alter, 2009).

The second important feature of this system is the balance that Andean Decisions strike between the interests of IP owners and those of consumers. As we explain below, the Andean Tribunal and domestic administrative agencies have rebuffed multiple efforts to expand IP protection of pharmaceuticals to include pipeline patents, second use patents, and data protection. As the case studies in this volume reveal, these actions have enabled Andean countries to maintain a balanced legal regime that limits the rights of private IP owners and expands the public's access to medicines.

Part I of this chapter explains how the repeated interactions between the IP administrative agencies and the ATJ helped to build an effective IP rule of law in Andean Community and to solidify pro-consumer interpretations of regional patent and trademark rules. Part II documents how ATJ judges and agency officials enabled Andean governments to resist pressure from the United States and its pharmaceutical industry to expand patent rights in violation of express limits on IP protection required by Andean IP rules. Part III evaluates the Andean Community's relative success in balancing the interests of IP owners and consumers. Part III also considers the broader implications for access to medicines in Latin America, drawing on examples from the national case studies in this volume.

\section{Constructing a Balanced IP Rule of Law in the Andean Community: The Relationship Between the Andean Tribunal of Justice and Domestic IP Agencies}

Over the last two decades, a powerful symbiotic relationship developed between the ATJ and the domestic IP agencies in the Andean member states. ${ }^{4}$ Beginning in the early 1990s, the agencies received a growing number of applications to register trademarks and patents. In reviewing those applications, officials identified gaps and ambiguities in Andean IP rules, and they actively sought the ATJ's guidance to address them. The agencies have helped to frame the legal questions that national courts later referred to the ATJ, they have participated in litigation before the Andean Tribunal, and they have provided information to ATJ judges to defend their registration decisions and substantive policy positions. ATJ jurisprudence, in turn, has been influenced by national IP agencies' broad subject matter competences — which include consumer protection, competition, and bankruptcy as well as IP - and a culture in which officials viewed themselves as engaged in highly skilled and technical activities.

\footnotetext{
${ }^{3}$ Of these 1338 rulings, $1165(87 \%)$ interpret Andean trademark laws; $103(8 \%)$ involve Andean patent; 11 (1\%) concern copyrights; and 24 (2\%) concern other IP rights. Only 35 cases (3\%) concern other legal issues.

${ }^{4}$ This relationship was strongest in Peru and Colombia and somewhat less developed in Ecuador and Venezuela. It was weakest in Bolivia, the least economically Andean Community member, which also has weaker judicial and administrative systems and limited IP-related foreign investment (Helfer, Alter and Guerzovich, 2009, at 22, 35-36).
} 
When referrals reached the ATJ, its judges responded by issuing decisions that bolstered the agencies' independence, transparency, and fidelity to the rule of law. The Andean Tribunal recognized that agencies were not immune from political interference. In response, it stressed the need for "administrative and economic autonomy to free officials from any kind of pressures or influences that derogate from" determining the interests of "the [IP] owner as well as the public or consumer.",

The ATJ also clarified and augmented the procedures that the agencies were to follow when reviewing patent and trademark applications. For example, the ATJ emphasized that officials had a responsibility to exercise particular care when IP applications are contested, including an obligation to articulate reasons for rejecting an opposition and to provide sufficient facts and legal analysis to enable the parties to challenge registration decisions in court. Taken together, these procedures helped to foster a hospitable climate for fair and evenhanded adjudication of IP registration disputes. ${ }^{6}$

As the agencies revised their procedures in response to ATJ rulings, their officials also influenced the Andean Tribunal's jurisprudence to reflect the officials' desire for IP rules that balance the interests of consumers and those of IP owners. In Peru, for example, the National Institute for Defense of Competition and Protection of Intellectual Property, better known by its Spanish acronym INDECOPI, included a division devoted to enforcing consumer protection laws and educating Peruvians about unlawful market practices. The agency developed an internal culture that held consumer rights in high regard. This culture also influenced the work of INDECOPI's administrative tribunal, whose decisions reviewing patent and trademark registrations and denials were later appealed to national courts and then referred to the ATJ. Over time, the agency's pro-consumer orientation influenced ATJ judges, preserving the public interest aspects of Andean IP rules (Helfer and Alter 2009, at 915-18).

The foregoing discussion reveals how the registration decisions of domestic IP administrative agencies, appeals to national courts, and preliminary references to the ATJ generated a positive feedback mechanism that helped build an effective IP rule of law in the Andean Community. Early ATJ rulings improved the agencies' procedures, promoted reasoned decision making, clarified ambiguities in Andean IP rules, and helped to insulate officials from domestic political pressure. The resulting climate of predictability and legal certainty encouraged firms to file an increasing number of applications for IP protection, notwithstanding the agencies' pro-consumer orientation. Many of these firms appealed the agencies' registration decisions to national courts. The judges on those courts, in turn, referred a growing number of cases to the ATJ, which further clarified Andean IP Decisions and administrative procedures. The cycle was completed when the Andean Tribunal's case law was applied by the same agencies whose registration decisions had spawned the first wave of ATJ referrals.

\footnotetext{
${ }^{5}$ Case 27-IP-95, at 15 (Oct. 25, 1996).

${ }^{6}$ See, e.g., Case 5-IP-99, at 6-8 (Oct. 25, 2000); Case 16-IP-2003, at 7 (Mar. 12, 2003); Case 44-IP-2006, at 10 (May 3, 2006); see also Case 35-IP-98 (Oct. 30, 1998) (instructing the national judge to determine whether the administrative agency had appropriately justified its decision).
} 


\section{Enforcing Andean IP Rules in Response to National Violations and Resisting Pressures for Stronger IP Protection of Pharmaceuticals}

The symbiotic relationship that developed between the ATJ judges and agency officials played a key role in three high-profile cases challenging domestic IP decrees as contrary to Andean law. The cases concerned Andean rules that restricted IP rights-specifically, pipeline patents, second-use patents, and five years of exclusive protection for pharmaceutical test datato achieve public interest and public health goals. The TRIPS Agreement does not require states to protect these rights. As a result, commentators generally describe a government that denies such protections as exercising the "flexibilities" that TRIPS provides to tailor domestic IP laws to other policy goals. ${ }^{7}$ In the Andean Community, in contrast, these restrictions on IP rights were mandatory. When adopting Andean IP Decisions, member states made a collective decision to capitalize on TRIPS' flexibilities as a way to promote public health. After these Decisions were adopted, however, the United States and U.S. pharmaceutical firms increasingly pressured individual countries to adopt stronger IP protection in violation of Andean law. The ATJ provided a forum for opponents of these efforts to push back.

In the pipeline patent case, decided in 1996, the ATJ invalidated a decree based on a bilateral IP agreement between Ecuador and the United States that extended the patent rights of foreign drug manufacturers. In the second-use patent case of 2001, the ATJ overturned a Peruvian decree - adopted in response to pressure by the U.S. pharmaceutical giant Pfizer - that authorized domestic IP agencies to grant second-use patents - including the lucrative patent for Viagra - in contravention of Andean law. And in the data protection case, decided in 2005, the ATJ found fault with a Colombian decree - adopted under pressure from the United States - that protects test data that pharmaceutical firms submit to the national health ministry when seeking approval to market new medicines. In each case, the ATJ and the domestic IP agencies provided a bulwark against pressure from the United States and its pharmaceutical industry to provide stronger IP protection of pharmaceuticals than Andean IP Decisions allowed.

\section{A. Enforcing the Ban on Pipeline Patents}

In the early 1990s, as part of an effort to conform regional IP rules to the soon-to-beadopted TRIPS Agreement, Andean governments for the first time recognized the patentability of pharmaceutical products. Aware that such protection would raise the price of medicines, the governments phased in protection incrementally. They recognized patents for new drugs developed after a major overhaul of Andean IP rules in 1992. But they refused to protect medicines patented in other countries during the years when it was impossible to apply for a pharmaceutical patent in any of the Andean countries. Although many of these foreign drugs were in the production "pipeline" before the change in Andean law, the member states nevertheless refused to recognize them in reliance on a theory of "absolute novelty."

\footnotetext{
${ }^{7}$ E.g. Musungu and Oh, 2005; Pires de Carvalho, 2010, at 62 ("The term 'flexibilities' means the alternative ways through which TRIPS obligations can be transposed into national law so that national interests are accommodated and yet TRIPS provisions and principles are complied with.").

${ }^{8}$ The doctrine of absolute novelty "implies that for an invention to be new and not to be included in the state of the art [and thus eligible for patent protection], it must . . . be known neither within the country where the patent is being sought, nor in any other country" (Manrique 1998).
} 
The United States, adopting the legal position of pharmaceutical firms, pressured the Andean countries to protect preexisting patented drugs. Most Andean states resisted this pressure. In 1993, however, Ecuador and the United States signed a bilateral treaty that mandated pipeline protection. Ecuador's legislature never ratified the treaty, but the country's president adopted a decree to implement it domestically. Relying on this decree, over the next two years the Ecuadoran IP agency awarded twenty-three pipeline patents to foreign pharmaceutical manufacturers such as Pfizer and Novartis.

In response, domestic generic drug producers successfully lobbied lawyers at the Andean General Secretariat to file a noncompliance suit against Ecuador alleging that the pipeline decree violated the absolute novelty requirement Andean Decision 344, which regulated patents and trademarks. Ecuador defended the domestic decree as consistent with a provision of the Decision authorizing members to adopt domestic legislation or international agreements that "strengthen the industrial property rights" (Andean Decision 344, Article 143 (1993)). The General Secretariat countered that the decree contradicted an unambiguous restriction in Andean patent rules and created an incentive for foreign firms to seek pharmaceutical patents in Ecuador but not in other member states. In a judgment issued in 1996, the ATJ sided with the Secretariat. The Tribunal interpreted the word "strengthen" in a teleological fashion, reasoning that national laws and treaties must complement the regional IP system, not contradict it. Ecuador had thus violated Andean IP law "by establishing an exceptional regime . . granting advantages to patenting in its own country, in a manner that was unfair under the common regime applied in the other Andean countries" (Manrique, 1998, at 217). The ATK also categorically rejected Ecuador's claim that "an international commitment [could] be invoked as a reason to validate noncompliance with a prior Community obligation" (Case 1-AI-96 (Oct. 30, 1996), at 30).

Within weeks of the ruling, the President of Ecuador adopted a decree revoking the prior law. Relying on the new decree, the domestic IP agency rejected at least 120 pending applications from foreign firms seeking to register pipeline patents (Helfer, Alter and Guerzovich, 2009, at 27). When the firms challenged the agency's denials, national courts referred the cases to the ATJ. The Andean Tribunal supported the agencies, reaffirmed its prior ruling, and stated categorically that "[a]ny patent requested on the basis of the pipeline principle must be denied or, if granted, nullified" Case 25-IP-2002, at 18 (May 8, 2002). Since the ATJ's 1996 judgment, the Ecuadoran IP agency has not granted any additional pipeline patents, and nor have the IP agencies in the other four member countries. The agencies thus played a key role in enforcing an important flexibility provision in Andean IP law.

\section{B. Enforcing the Ban on Second-Use Patents}

Andean IP Decisions contain a second flexibility provision relating to access to medicines - a prohibition on second-use patents. ${ }^{9}$ This ban was contested by the American pharmaceutical company Pfizer, which filed second-use patent applications in all Andean countries after discovering, in the mid-1990s, that its heart medication pyrazolpyrimidinones

\footnotetext{
${ }^{9}$ Andean IP law categorically reject second-use patents: "Products or processes already patented and included in the state of the art ... may not be the subject of new patents on the sole ground [that the product was] put to a use different from that originally contemplated by the initial patent." Decision 486, Article 21; Decision 344, Article 16.
} 
(Viagra) had the side effect of treating male impotence. In Peru, INDECOPI applied Andean IP law and rejected the company's application. A few months later, President Alberto Fujimori issued a decree recognizing second-use patents in direct contravention of Andean law. Pfizer then asked INDECOPI to reexamine its patent applications. Relying on the new decree, the agency granted the applications. Pfizer then threatened to sue Peruvian firms that were manufacturing or selling generic versions of Viagra.

With domestic litigation looming, the Association of Pharmaceutical Industries of National Origin (ADIFAN), a trade association of generic drug firms, filed a complaint with the Andean General Secretariat. The Secretariat upheld the complaint and submitted the case to the ATJ. In a 2001 judgment, the Tribunal agreed with the generics companies that Fujimori's decree violated the ban on second-use patents in Andean law, and it directed Peru "to leave without effect the patent granted to" Pfizer (Case 89-AI-2000, at 40). ADIFAN then petitioned INDECOPI to revoke the patent for Viagra, and the agency did so several months later. Peru never repealed the domestic decree, but neither did it pressure INDECOPI to enforce it. This suggests that the government was willing to circumvent Andean law but unwilling to challenge agency officials or the ATJ on behalf of Pfizer-actions that would have involved a more serious challenge to the Andean legal system. Since the Viagra case, INDECOPI has not granted any second-use patents.

Litigation in Venezuela and Ecuador followed a similar pattern. The IP agency in each county registered a second-use patent for Viagra prior to the ATJ ruling against Peru, and national associations of generic drug companies turned to the Andean legal system to challenge the registrations. When the General Secretariat and the ATJ reaffirmed their prior rulings, the agencies reversed their positions and invalidated the patents. ${ }^{10}$ In Colombia, the IP agency was bolder - it rejected Pfizer's application. The company then appealed to a national court, which referred the case to the ATJ for a preliminary ruling. The Tribunal reiterated the ban on second use patents and the court implemented the ATJ's decision (El Tiempo, 2009).

As a result of this wave of litigation, all of the domestic IP agencies in the Andean Community denied or annulled patents for Viagra. This region-wide refusal to recognize second-use patents remains a major irritant to the U.S. pharmaceutical firms. The industry's 2008 Special 301 Report to the Office of the U.S. Trade Representative places the blame squarely on the ATJ. The report criticized the Tribunal for "issu[ing] several legal opinions ... forcing Andean Community members to refuse recognition of patents for second uses[.] The [ATJ] position is dispositive on the issue and no further domestic appeals/remedies are possible" (PhRMA, 2008, at 236).

\section{The Politics of Data Protection and the Reversal of an ATJ Ruling}

The third Andean IP noncompliance dispute concerns the test data that drug companies submit to domestic health ministries when seeking approval to market new medicines. The pharmaceutical industry favors laws that give patent owners the exclusive right to control such

\footnotetext{
${ }^{10}$ Case 01-AI-2001, at 39 (June 27, 2002) (judgment against Venezuela); Case 34-AI-2001, at 51-52 (Aug. 21, 2002) (judgment against Ecuador); see also Pacheco and Nebrada, 2006.
} 
data. Absent such protection, the industry claims, competitors can unfairly rely on the drug companies' data without conducting their own safety tests.

Disputes over data protection in the Andean Community have a long history. Decision 344, adopted in 1993, prohibited the disclosure of unpublished test data - a form of legal protection mandated by TRIPS. ${ }^{11}$ But the Decision also made this protection exclusive for five years; in contrast, TRIPS did not mandate a specific term of protection, requiring only that the data should not be put to "unfair commercial use."12 Some Andean governments interpreted this language as permitting a shorter period of protection. During negotiations to revise Decision 344 , the issue sharply divided the member states. The region was home to a large generics industry, which would benefit from less stringent protection of test data. But the United States and U.S. pharmaceutical firms were pressuring Andean countries to maintain the five-year period of data exclusivity and include it in a draft U.S.-Andean trade agreement. In the end, the new Andean legislation-Decision 486, adopted in 2000 - removed the reference to a five-year term of exclusivity and instead simply required protection of test data "against any unfair commercial use." The key provision of Decision 486 also added an ambiguous final sentence allowing member states to "take the necessary action to guarantee the protection provided for in this article." 13

Relying on this provision, in 2002 Colombia enacted a domestic decree that granted up to five years of exclusive protection for test data. The Association of Colombian Pharmaceutical Industries (ASINFAR) promptly challenged the decree, but the General Secretariat upheld the law as permitted under the above-quoted sentence. ASINFAR appealed to the ATJ, which rejected the Secretariat's interpretation - a first in IP litigation before the Andean Tribunal—and held that the Colombian decree violated Decision 486. The judges reasoned that data protection must be interpreted in light of the Andean Community's interest in promoting public health, interests that precluded Colombia from enacting data protection rules that deviated from the regional standard. ${ }^{14}$

The ATJ's ruling had immediate consequences for the ongoing free trade talks with the United States. Andean governments made clear to their American counterparts that a five-year period of exclusivity was now "off the table." In an effort to save the decree and the negotiations, the Colombian Ministry of Foreign Trade asked the other member states to clarify that the country's 2002 decree was consistent with Andean Decision 486. All prior Decisions had been approved by consensus, but on this issue the governments were deadlocked. After

\footnotetext{
${ }^{11}$ Andean Decision 344, Articles 78 \& 79. Article 79 provides:
}

No one other than the person who has supplied the data referred to in [Article 78] may, without the latter's authorization, invoke that data in support of an application for the approval of a product during a period of not less than five years following the date on which the Member Country granted approval for the marketing of the product to the person who produced the data.

${ }^{12}$ TRIPS, Article 39.3.

${ }^{13}$ Andean Decision 486, Article 266.

${ }^{14}$ Case 114-AI-2004, at 41 (Dec. 8, 2005) ("[T]he Community interest that must regulate the marketing of pharmaceutical products . . . is directed to the protection of public health and the improvement of the standard of living of the inhabitants of the subregion."). 
several attempts to reach agreement failed, the Andean Commission (a body comprised of executive branch officials from each member country) scheduled a meeting for April 2006. Bolivia and Venezuela were unable to vote at that meeting because they had not paid their membership dues. In their absence, the remaining three states adopted Andean Decision 632 by consensus. The Decision "clarifies the intent of the legislators . . that each Member Country shall have the authority to choose the means for protecting test data, including the possibility of establishing time periods" of exclusive protection - a retroactive validation of the Colombian decree (Decision 632, 2006, preamble).

This resolution of the data protection dispute exacerbated an already tense political climate in the Andes. Regional trade negotiations broke down in late 2005 when Peru and Colombia agreed to negotiate bilateral trade agreements with the United States that require a five years of test data exclusivity. In contrast, Bolivia, Ecuador, and Venezuela do not provide for such protection, nor have they entered into bilateral trade agreements with the United States. These divisions triggered Venezuela's withdrawal from the Andean Community two weeks after the adoption of Decision 632. "President Chavez stated publicly that the reason for the withdrawal was the entry of other member countries into free trade agreements with the United States ..." (USTR, 2007 at 621). Officials in Colombia's foreign trade ministry concurred, but characterized Decision 632 as the "last straw" in precipitating Venezuela's break with the regional integration pact. ${ }^{15}$

$* * * * * * *$

Two common threads tie together the pipeline patent, second-use patent, and data protection cases. First, rulings by the ATJ made it more difficult for individual member countries to defect from Andean Community IP policies in response to demands for stronger IP protection of pharmaceuticals by the United States and U.S. firms. In the pipeline and seconduse cases, national judges and agency officials initially followed domestic decrees that benefitted U.S. drug companies but violated Andean IP Decisions. These actors changed course, however, after the ATJ invalidated the decrees and ordered the agencies to overturn patents registered based on the decrees. National governments acquiesced in these reversals, even though the conflicting degrees nominally remained on the books. The outcome of the third case - data protection-was more equivocal. Colombia argued that the ATJ had erroneously interpreted an ambiguity in Andean IP law. Rather than openly defy the Andean Tribunal's ruling, however, Colombia orchestrated the adoption of a new Decision (one that permits but does not require data exclusivity) using a procedure in Andean law for states to interpret regional legislation.

Second, domestic IP agencies were important behind-the-scenes actors in all three cases. The agencies had a stake in Andean IP laws, a stake that the Andean General Secretariat nurtured in the late 1990s during the drafting of Decision 486. The General Secretariat consulted agency officials to ensure that the new IP legislation rectified concerns and closed lacunae in the prior regional IP law-Decision 344, adopted in 1994 (Helfer, Alter and Guerzovich, at 12-13). Having contributed to the content of Andean IP Decisions, the agencies had an interest in upholding them. When governments tried to circumvent the Decisions, agencies were put in a

\footnotetext{
${ }^{15}$ Interviews at the Colombia Ministry of Trade, Industry and Tourism, Bogotá (Sept. 14, 2007).
} 
difficult position. They could not ignore legally valid domestic decrees. But they also recognized that Andean IP law_- "their" law_-was being sidestepped in ways that could undercut low-cost access to medicines. The ATJ may have been willing to push back against the decrees because it knew that agency officials would support its rulings. The symbiotic relationship between the ATJ and the agencies can be summed up as follows: domestic IP agencies are committed to following Andean IP Decisions as interpreted by the Andean Tribunal. This commitment, in turn, has enabled the ATJ to hold governments to regional IP standards.

The cooperative relationship between Andean judges and administrative agencies helped the ATJ to enforce pro-consumer Andean IP rules in the three cases discussed in this section. Nevertheless, the United States and its pharmaceutical industry have continued to pressure governments in Latin America to provide stronger IP protection for new medicines. Such pressure is unrelenting, and over time the United States has won important concessions, principally through the negotiation of bilateral trade treaties containing TRIPS-plus standards. The bilateral free trade agreements with Colombia and Peru are notable examples. ${ }^{16}$ For these three issues, however, Andean countries have been more successful than their neighbors in maintaining key elements of a more balanced approach to IP, one that seeks to reconcile the social and economic needs of developing countries with the interests of private rights holders.

\section{Lessons of the Andean Experience for Access to Medicines in Latin America}

The experience of the Andean Community, summarized above, offers four insights for understanding the relationship of IP and access to medicines in Latin America. First, it highlights the importance of examining how international IP norms are incorporated into national legal systems. Second, the Andean experience foregrounds the role of administrative agencies in shaping whether patents and data protection are barriers to access to medicines. The third lesson relates to whether local generics industries can effectively advance broader public interest goals relating to the human right to health. The final insight highlights the wider administrative and regulatory contexts in which Andean IP rules are embedded.

\section{A. Domesticating International IP Norms}

Most studies of the relationship between IP protection and access to medicines focus on international instruments such as the TRIPS Agreement, TRIPS-plus treaties, the Doha Declaration on TRIPS and Public Health, and emerging treaties, such as the Anti-Counterfeiting Trade Agreement (Ho, 2011; Pogge, Rimmer and Rubenstein, 2010; Yamane, 2011). These studies closely analyze these international instruments to identify the flexibilities they contain and the policy discretion they afford to governments. The studies give less attention, however, to how international IP instruments are incorporated into national legal systems. They mainly focus on high-profile issues, such as compulsory licenses, or on economically important developing

\footnotetext{
${ }^{16}$ Bilateral treaties are also driving IP lawmaking in the Andean Community. The most recent Andean IP legislation, Decision 689, adopted in August 2008, gives individual member states greater leeway to strengthen domestic IP protection rules. Colombia and Peru lobbied for the Decision to enable them to comply with their respective bilateral treaties with the United States (Barreda, 2008; Kelechava, 2008).
} 
nations, most notably Brazil (Bird and Cahoy, 2008), India (Kapczynski, 2009), South Africa (Forman, 2008; Klug, 2008), and Thailand (Ho, 2009). ${ }^{17}$

Our studies of the Andean legal system add to this literature in two important respects. First, unlike the countries listed above, the national IP legislation of Bolivia, Colombia, Ecuador, Peru and (until 2006) Venezuela is Andean law-law that is negotiated at the supranational level and has direct domestic effect. Domestic IP administrative agencies across the region apply these supranational rules to determine whether to register patents and trademarks, the agencies exchange best practices when they confront unclear aspects of the law, and governments ask for the agencies' views when revising supranational IP rules. These features give agency officials a stake in ensuring that Andean IP Decisions are respected.

Second, Andean governments decided to incorporate TRIPS flexibilities as obligatory features of Andean law to promote public health goals and encourage local generics industries. This approach differs from other Latin American countries, which view the flexibilities as helpful - but not mandatory - instruments of state policy. As a result, these countries have often succumbed to U.S. pressure to recognize pipeline and second-use patents and to provide a multiyear term of protection for pharmaceutical test data (Helfer, Alter and Guerzovich, 2009, at 28, 30, 34). For example, Brazil is among the most aggressive countries in Latin America in threatening and invoking TRIPS flexibilities such as local working requirements and compulsory licenses. Yet Brazil also recognizes pipeline patents for pharmaceuticals, even though it has not ratified any TRIPS-plus treaties that require such protection and notwithstanding trenchant critiques of pipeline protection by commentators (Giuse, 2010).

In the Andes, the existence of a supranational venue for IP lawmaking helped to ensure that TRIPS flexibilities were given effect. Generic drug companies worked with the General Secretariat to protect their interests, and the Secretariat ensures that Andean IP rules took into account consumer interests. We are uncertain why the actors discussed in the other chapters in this volume - such as national judges and civil society groups - have had less influence in shaping the balance between IP protection and access to medicines in other countries. We suggest that one answer may be the absence of a supranational legal system whose competence includes IP issues. All of the actors we interviewed in the Andes-agency administrators, lawyers, generic drug producers, and Andean officials - indicated that national judges were generally uninformed about IP law. They also expressed a preference for balancing patent protection, consumer rights, and access to medicine at the supranational rather than the national level—a possibility that does not exist elsewhere in South America.

\section{B. The Underappreciated Role of Domestic Administrative Agencies}

Scholars of IP and human rights have long recognized the importance of national courts in interpreting and applying international law (Benvenisti 2008; Dinwoodie, 2000; Helfer and Slaughter 1997). Courts can construe domestic laws in harmony with treaty obligations, they can adapt international norms to national values, and they can serve as compliance partners for the

\footnotetext{
${ }^{17}$ Far fewer studies (e.g., Bernieri, 2006; Kunisawa, 2009; Shadlen, 2011; Shadlen, 2009) have addressed the relationship between IP and access to medicines in Latin America.
} 
rulings of international tribunals. Only recently, however, have commentators given equal attention to the analogous functions performed by domestic administrative agencies. Peter Drahos' comprehensive comparison of national patent offices is a prominent recent example, as are analyses of national human rights institutions (Drahos, 2010; Mertus, 2009; Murray, 2007).

Our research reveals that administrative agencies are more important compliance partners than national courts in ensuring implementation of Andean IP rules and in balancing IP against other priorities. One reason is that the IP agencies in Colombia and Peru are also charged with protecting consumers and policing markets. Another is the history of Andean IP policy, which had long required only minimal patent protection for pharmaceuticals as a strategy to promote public health and nurture local generics industries. Governments changed course in the 1990s when they adopted TRIPS-compatible IP rules for new drugs. But the memory of IP as an tool of social policy lived on and was carried forward by administrative agency officials as they implemented Andean rules governing IP, consumer protection, and competition law.

The contributions to this volume highlight other ways in which administrative agencies are important to IP implementation politics. The first example concerns the authority of Brazil's National Health Surveillance Agency (ANVISA) to review applications for pharmaceutical patents previously considered by the country's National Institute of Industrial Property (INPI). This dual review mechanism promotes the rigorous examination of patent applications and prevents the granting of drug patents that have adverse public health consequences. ${ }^{18}$ But this shared competence has also engendered competition between the agencies and constitutional challenges from the pharmaceutical industry, challenges that now appear to have succeeded. The second example relates to the patent "linkage" mechanism that prevents national health ministries from approving generic medicines for distribution without first confirming that active ingredients are not protected by a patent. ${ }^{19}$ As a result of the linkage requirement, "drug regulatory offices are mandated to ensure that products they license are in full compliance with IP law," a task they "are neither trained nor funded to do.",20

\section{Generics Industries and the Public Interest}

Another theme that connects the case studies to our analysis of the Andean Community is the prominent role of generic drug companies and industry associations. In the Andean context, these companies and associations had powerful financial incentives to oppose domestic IP decrees that make it more difficult to distribute cheaper copies of patented medicines. In lawsuits challenging these decrees, representatives of the generics industry raised a variety of legal arguments, including not only the violation of Andean IP Decisions but also the contravention of consumer protection principles and the human right to health.

\footnotetext{
${ }^{18}$ Mônica Steffen Guise and Adelina de Oliveira Novaes

${ }^{19}$ Salvador Millaleo

${ }^{20}$ The United States has included linkage requirements in TRIPS-plus treaties adopted by several countries in Latin America. Angelina Snodgrass Godoy, CAFTA, Intellectual Property, and the Right to Health in Central America
} 
So long as the generics industry focused its opposition on TRIPS-plus patents, its private interests more or less aligned with the broader public interest. As the contributions to this volume reveal, however, such an alignment cannot be taken for granted. Generics companies have not shied away from asserting IP rights to gain or preserve market share or otherwise advance their commercial interests. The prevalence of branded generics in Argentina, with prices that exceed those of their proprietary cognates, is a prominent illustration. ${ }^{21}$ Public interest civil society groups have recognized that the generics industry does not always act as proxy for efforts to expand access to medicines. As result, these organizations have, with considerable success, challenged the lack of access as a violation of the rights to life and health guaranteed in national constitutions ${ }^{22}$ and in the American Convention on Human Rights. ${ }^{23}$

\section{Situating the Andean Experience in a Wider Context}

Our research reveals how the Andean Tribunal, domestic administrative agencies, and generic drug companies contributed to building an IP rule of law in the Andean Community that balanced IP rights against public health goals. Our interviews with these actors also suggest a somewhat less hopeful prediction for future efforts to expand access to medicines in Latin America.

First, it is worth recalling that prior to the early 1990s, Andean IP law, like that of most developing countries, did not provide any patent protection for pharmaceutical products. Seen from this vantage point, "absolute novelty"- the legal doctrine that underpins Andean law's ban on pipeline and second-use patents-was a major concession by proponents of access to medicines. For domestic IP agencies, however, this concession was uncontroversial. Governments created the agencies in the 1990s when they they revised Andean IP rules. They staffed the agencies with pro-reform economists, lawyers and administrators, many of whom had foreign training or work experience. These officials accepted a global IP regime as a given. But they also prioritized the development of balanced rules that would help local actors - both businesses and consumers - to capture the benefits of IP protection. ${ }^{24}$ Although opinions differed over where to strike the balance, all of the participants we interviewed recognized the advantages of developing Andean-wide IP legislation. For access to medicines advocates, such legislation helped national actors resist foreign pressures to circumvent legal doctrines such as

\footnotetext{
${ }^{21}$ See Paola Bergallo and Agustina Ramón Michel, The Recursivity of Global Lawmaking in the Fight for an Argentine Policy on Drug Patents

${ }^{22}$ For example, many high courts in Latin America, including in Argentina, Colombia, Costa Rica, Peru, and Venezuela have recognized a right of patients with HIV/AIDS to medical treatment, including anti-retroviral medications, under their national constitutions (Oquendo, 2008; Yamin and Parra-Vera 2009).

${ }^{23}$ In Jorge Odir Miranda Cortez et al v. El Salvador, Case 12.249, Report No. 29/01, OEA/Ser.L/V/II.111 Doc. 20 rev. at 284 (2000), for example, the Inter-American Commission on Human Rights found admissible a claim that El Salvador had violated the right to life, health and wellbeing of HIV/AIDS patients by failing to provide them with triple therapy medication. While the claim was pending the government approved provision of anti-retroviral therapy for persons with HIV or AIDS, and the case ended in a friendly settlement.

${ }^{24}$ The IP agencies also helped local firms and entrepreneurs secure trademark protection for their goods and services. The agencies worked hard to make the trademark registration process affordable and relatively simple for small businesses without the need for legal assistance. The result has been a rapid rise in local demand for trademarks and an increase in trademark oppositions (Helfer, Alter and Guerzovich, 2009, at 18-19).
} 
absolute novelty. For businesses seeking to market products in multiple countries, common regional standards were preferable to disparate national standards.

Second, our focus on the substantive content of Andean IP Decisions omits other factors - such as changes in industry regulations - that may also affect access to medicines. One anecdote from our interviews is illustrative. According to the President of the Colombian generics manufacturers association ASINFAR, the number of laboratories producing medicines in that country declined from more than 275 in 1995 to just over 100 at the end of 2000 . The President identified two causes of this decline. First, new production standards required investments that were too onerous for many local producers to meet, and these producers simply went out of business. Second, for multinational drug companies, the new standards - together with liberalized access to the Colombian market - made drug production in other countries economically attractive. ASINFAR's President estimated that, by 2007, ninety percent of all pharmaceuticals distributed in Colombia were produced elsewhere. ${ }^{25}$ These changes highlight the importance of considering how the broader regulatory environment intersects with substantive IP rules to influence the scope of access to medicines.

\section{Conclusion}

IP protection and access to medicines are in an uneasy and often contested relationship in Latin America. In the Andean Community, an alliance between domestic IP administrative agencies and the Andean Tribunal enabled governments to resist pressures from the United States and foreign pharmaceutical firms to circumvent Andean IP rules that facilitated access to medicines. This alliance was at its zenith from the mid-1990s to the mid-2000s, a decade during which generic drug companies repeatedly and successfully challenged domestic degrees that expanded IP protection of pharmaceuticals. More recently, political and economic fractures among Andean Community member states have hampered regional cooperation efforts and enabled the United States to negotiate TRIPS-plus agreements with Colombia and Peru. Even so, Andean IP law retains restrictions on IP — such as a ban on pipeline and second-use patentsthat many other Latin American nations abrogated in response to foreign pressures. The Andean Community's experience thus provides important insights for governments, civil society groups, and individuals seeking to expand access to medicines throughout the region.

\footnotetext{
${ }^{25}$ Interview with the President of the Associación de Industrias Farmacéuticas Colombianas (ASINFAR), Sept. 14, 2007.
} 